\title{
Produção, Circulação e Significados do Artesanato Pataxó no Contexto Turístico da aldeia de Coroa Vermelha, Santa Cruz Cabrália-BA ${ }^{1}$
}

\section{Sandro Campos Neves ${ }^{\mathrm{i}}$}

Universidade Federal Rural do Rio de Janeiro

Resumo: O artesanato Pataxó na aldeia de Coroa Vermelha sempre esteve ligado ao caráter de entreposto da região. No contexto do turismo de massa realizado na região a partir de 1970, esse artesanato ganha novos contornos de significação. A partir do ano 2000 é criado um centro de artesanato indígena na região. Realizei um levantamento com 28 das 300 lojas Pataxó no verão de 2010 a respeito de aspectos da circulação, produção e significação do artesanato indígena. Em relação à produção, o artesanato Pataxó sofre grande padronização na apresentação. No processo de circulação desse artesanato ocorre uma apropriação desigual de sua rentabilidade. São apresentados dois grandes tipos de significado para o artesanato; arte local ou souvenir turístico.

Palavras-Chave: Produção; Circulação; Significado; Artesanato Pataxó; Turismo

Title: Pataxo craft and tourism: Production,circulation and meaning at Coroa Vermelha Village, Santa Cruz Cabralia, Bahia State

\begin{abstract}
Pataxó craft made at Coroa Vermelha village has always been a part of the warehouse activities held at the region. As mass tourism grew since 1970, this craftsmanship acquires new meanings. In 2000, a center of native handicrafts was created. During the summer of 2010 a survey with 28 of 300 Pataxó stores was conducted to investigate circulation, production and meaning of native handicrafts. Regarding production, Pataxó craftsmanship suffered a great standardization in . Regardint circulation process an unequal appropriation of profitability was found. As for meaning, two kinds were observed, handicraft is either local art or touristic souvenir.
\end{abstract}

Keywords: Production; Circulation; Meaning; Pataxó Craft; Tourism

i Professor Assistente do Curso de Turismo. Doutorando em Antropologia na Universidade Federal da Bahia. Email: sandrocamposneves@yahoo.com.br 


\section{Introdução}

A aldeia Pataxó de Coroa Vermelha, lócus dessa pesquisa, se localiza a aproximadamente $17 \mathrm{~km}$ do centro do município de Porto Seguro e faz parte do município de Santa Cruz Cabrália, do centro do qual dista cerca de $8 \mathrm{~km}$. Até então considerada apenas um bairro de Santa Cruz Cabrália, a região foi reconhecida e demarcada como Terra Indígena em 1996. A partir dessa data, a Terra Indígena Coroa Vermelha passou a se constituir de uma área de 1420 hectares às margens da $\mathrm{BR}$ 367, na praia de Coroa Vermelha, denominada Gleba B e uma área de 72 hectares, distante cerca de $7 \mathrm{~km}$ da praia de Coroa Vermelha em direção à Mata. (Sampaio, 1996)

A ocupação da região pelos Pataxó se inicia na década de 1970, sendo o comércio de artesanato, desde então, uma das principais atividades econômicas e provavelmente a mais lucrativa, considerando-se sua sazonalidade. A idéia inicial parece ter sido a de que o comércio na região seria favorecido pelo seu papel de entreposto, ocasionado pela chegada de duas estradas federais, a BR 367 e a BR 101 à região. No entanto, terminada a construção desses trechos de estradas federais, elas ocasionam também a chegada massiva de turistas à região. A partir desse movimento os Pataxó passam a, decisivamente, ter na venda de artesanato, agora aos turistas, uma atividade econômica fundamental.

A produção de artesanato, no entanto, muito além de mera atividade econômica, tem sentidos fundamentais ligados à construção e articulação da identidade étnica, podendo ser considerada sinal diacrítico (Barth, 2000). De fato, ao longo da historia dos órgãos de tutela indígena no Brasil, a produção de artesanato, bem como o uso de uma língua e de rituais próprios, foram entendidos como os demarcadores da identidade indígena (Peres, 2004). Embora o valor real de cada um desses marcadores, dentro da lógica interna de cada povo, seja bastante relativizado é fato que para uma avaliação externa são fundamentais, quando se trata de reco- nhecimento, principalmente por leigos, da indianidade de determinada comunidade. Assim, além de se constituir numa atividade econômica fundamental, a produção e comércio de artesanato se tornam pilares da afirmação da indianidade Pataxó.

$\mathrm{O}$ artesanato Pataxó, dada sua importância na luta desse povo pela subsistência, movimenta diversas aldeias e esforços organizados de inúmeros sujeitos, num fluxo que culmina na venda aos turistas em Coroa Vermelha. Nesse trabalho, pretendo discutir alguns aspectos desse fluxo de artesanato que culmina na aldeia de Coroa Vermelha, mas envolve diversas outras, bem como envolve uma dialética de significação atribuída ao artesanato. Essa dialética teria, acredito, muito a dizer sobre os desdobramentos contemporâneos dos processos de "modernização" envolvendo povos indígenas e o contexto da globalização e a respeito das formas como se dá o diálogo intercultural.

Procurarei construir nesse trabalho uma interpretação do artesanato que busque analisar sua existência como uma forma de continuidade na tradição indígena. Embora tenha sido amiúde demonstrado, entre outros por Grunewald (1999), que o artesanato Pataxó, em seu formato atual, começa a ser produzido na década de 1970 , proponho uma interpretação que procure enxergá-lo como persistência da tradição. Por um lado, a literatura demonstra que o lapso de tempo em que houve descontinuidade é aparentemente curto, pois há uma constância ao menos na memória da tradição artesanal. Por outro, procura-se conceber a tradição aqui para além dos objetos, como um modo de ver, de ser e de fazer que caracteriza a relação com a história mantida por determinado grupo social.

Este texto é resultado do trabalho de campo realizado entre os Pataxó desde 2005, embora se articule de maneira mais sistemática a partir de 2008, bem como de um levantamento de campo, realizado no centro de artesanato Pataxó da Coroa Vermelha no verão de 2010. A metodologia utilizada para o trabalho de campo é eminentemente qualitativa, em conformi- 
dade com a proposta de pesquisa etnográfica, embora, no caso do levantamento de campo, tenha sido empregada uma metodologia quantitativa. Nesse levantamento questionei 28 comerciantes indígenas, de um universo de 300 trabalhando no verão de 2010. Esses dados ajudaram a delinear o que já havia sido percebido pela observação participante em relação aos fluxos do artesanato entre as aldeias Pataxó, além de colaborarem para compreender alguns aspectos de sua produção, uso e significados.

\section{O Parque Indígena: breve descri- ção do contexto da pesquisa}

Na aldeia Pataxó de Coroa Vermelha, existe desde o ano de 2000, um centro de artesanato, um estacionamento e o símbolo da cruz, conhecido como "o cruzeiro" entre os índios, que representa o local da primeira missa. Essas referências já existiam antes, no entanto, como marco de comemoração dos 500 anos de Descobrimento, o governo federal à época construiu uma nova estrutura. Reformulou-se o centro de artesanato, antes composto por barracas de praia, agora uma bela construção de madeira e palha de estilo rústico e referências à estética indígena. O estacionamento teve o chão de terra cimentado e recebeu uma guarita para fiscalização de entrada e saída. Foram construídos também; um novo símbolo da cruz da primeira missa e um museu indígena, estabelecendo um complexo indígena na região. É a esse complexo que os Pataxó chamam de Parque Indígena.

Nesse processo, foram retirados da região os comerciantes não-indígenas e foi construído para estes um centro de artesanato, conhecido como "shopping dos brancos". No momento de construção do centro de artesanato indígena, a solução encontrada para contemplar aos interesses indígenas tinha sido a de que seriam construídas lojas, no formato de ocas (ou Quigemes no termo Jê utilizado pelos Pataxó). Estas seriam doadas àqueles comerciantes e famílias que já possuíam sua loja no esquema anterior, de barracas de praia.

Estes Quigemes, construídos na beira da praia ficam dispostos formando uma rua ladeada por duas fileiras de barracas, que leva à cruz comemorativa dos 500 anos. À esquerda de quem caminha por essa rua em direção à praia fica uma construção circular, em formato de Quigeme. Essa construção possui 40 metros de diâmetro, em formato circular é composta por várias lojas e constitui o Centro de Artesanato Indígena. $\mathrm{Na}$ verdade trata-se de uma parte dele, já que o mesmo estende-se até a praia, mas os índios o consideram um espaço diferenciado, por ser ocupado apenas por lojistas indígenas. Nele ficam localizadas algumas das lojas dos comerciantes do centro e, atrás dele, fica localizado o estacionamento, utilizado por banhistas que vão à praia de Coroa Vermelha e ao centro de artesanato.

\section{Administração do Parque Indíge- na: gestão do conflito e controle local sobre o artesanato e seus fluxos.}

O momento da comemoração dos 500 anos de Descobrimento, de acordo com a narrativa indígena, foi especialmente emblemático e problemático para os Pataxó. Emblemático, pois foi o momento onde se destacaram no cenário nacional, estabelecendo para si uma posição simbólica de povo do Descobrimento, aqueles que lá estavam quando do achamento do que viria a ser o Brasil. Embora essa posição tenha seus problemas do ponto de vista da historiografia local, ela exerce o efeito de atribuição de status social que a posição confere. Problemático, por outro lado, pois no mesmo momento em que os Pataxó recebiam inédita atenção do Estado brasileiro, alguns movimentos e protestos indígenas na região foram duramente reprimidos pela polícia estadual, restabelecendo o antigo descaso do poder público com a causa indígena. Além dessa questão, havia ainda o desafio de criar uma forma de administrar os ganhos obtidos com o episódio da comemoração dos 500 anos. Era preciso equilibrar a distribuição de benefícios 
entre o maior número possível de índios e, ao mesmo tempo, garantir que os ganhos fossem duradouros.

A solução para as lojas do centro de artesanato se baseou então no fato de que diversas famílias já possuíam lojas e que, por isso, deveriam ter o direito de ficar com as novas lojas construídas pelo governo. No entanto, como resolver o problema de fazer essas conquistas durarem? Os Pataxó, desde aquele momento, no ano 2000, estabeleceram uma gestão do Parque Indígena, diferenciada da gestão do cacique. Essa diferenciação não se estabeleceu como uma quebra de hierarquia ou diminuição do poder do cacique, mas como uma divisão administrativa. Embora exista uma diferenciação entre o cacique e o administrador do Parque, na prática o administrador está subjugado ao poder do cacique. Embora haja relativa liberdade administrativa, em última instância, vale a palavra do cacique.

De toda forma, essa gestão do Parque Indígena, eleita a cada dois anos, se ocupa dos problemas mais cotidianos do centro de artesanato, do museu e do estacionamento. Grande parte das receitas que mantém a gestão do cacique, bem como as que são utilizadas para a construção de benfeitorias em toda a comunidade vem da administração do Parque. O estacionamento, utilizado tanto por pessoas que vão à praia de Coroa Vermelha quanto pelas que vão ao centro de artesanato indígena é, entre as três estruturas que compõem o Parque, uma das melhores e a mais rentável fonte de renda, que garante a manutenção das instâncias de poder Pataxó.

A necessidade do estabelecimento de uma gestão específica para o Parque Indígena não diz respeito, no entanto, apenas à administração burocrática, ela é também um eficiente instrumento de gestão do conflito. É preciso ter em conta que grande parte dos interesses financeiros mais diretos de indivíduos e famílias de Coroa Vermelha e até de outras aldeias da região passam pelo centro de artesanato. $\mathrm{O}$ que define em muitos casos a maior ou menor prosperidade de famílias inteiras é a receita do artesanato. As outras receitas e práticas de subsistência - doações da $\mathrm{FUNAI}^{2}$, programas sociais (bolsa-família, etc), agricultura, coleta, empregos fora da aldeia - estabelecem um relativo equilíbrio, até por sua distribuição controlada e administrada deliberadamente para equalizar. O sucesso comercial no centro de artesanato é, então, um diferenciador social importante na aldeia de Coroa Vermelha.

Por essa razão, não são poucos os conflitos entre indivíduos e famílias em função das decisões que envolvem o Parque Indígena. Um exemplo corriqueiro pode ser ilustrado com um relato do atual administrador do Parque. O "Kapimbará" me dizia, no verão de 2010, que começara a instalar portões para fechar o acesso ao centro de artesanato, principalmente durante o período noturno. Essa era uma reivindicação dos próprios donos de lojas, mas vinha sendo recebida com bastante amargor pelas famílias que habitavam as imediações do centro de artesanato. De acordo com o Kapimbará, estavam ocorrendo problemas no período da noite, com pessoas entrando no centro de artesanato e "fazendo sujeira". Essa situação, segundo ele, causadas "pelos próprios índios", que seriam seus autores, atrapalhava os negócios, pois os comerciantes eram obrigados a fazer a limpeza do local antes de abrir as lojas, atrasando o início do trabalho.

Por outro lado, para as famílias que residiam nas imediações o fechamento do acesso ao Parque, ainda mais no período noturno, significava fazer um desvio considerável antes de chegar em casa ao final do dia. Um conflito que à primeira vista se trata de um simples conflito de vizinhança, opõe de um lado famílias mais prósperas, que possuem lojas e vivem do comércio de artesanato e, de outro, famílias menos prósperas, muitas vezes produtoras do artesanato, mas sem a possibilidade de possuírem lojas. Este segundo grupo de famílias, que em geral habitam as imediações do centro de artesanato, se sente então duplamente excluído, por um lado da possibilidade de atuar no centro 
de artesanato e, por outro, pelo acesso a ele fechado, ainda que se constitua em um atalho no caminho para casa.

Cabe à administração do Parque Indígena mediar esse conflito. Por um lado, está claro que ela privilegia, de certa forma, os interesses dos comerciantes, nesse caso específico, pois instalou os portões. Por outro lado, procurarei mostrar, ao longo desse trabalho, de que formas a administração do Parque Indígena busca minorar os efeitos da desigualdade de apropriação da renda do comércio de artesanato, realizando inclusive a construção de benfeitorias com parte de seus recursos, auferidos através dos comerciantes.

\section{A produção do artesanato Pataxó: aspectos estruturantes da circu- lação}

O conflito sobre o centro de artesanato indígena possibilita proceder a uma primeira explicação sobre a produção de artesanato em Coroa Vermelha. Em primeiro lugar é preciso dizer que quando falo em artesanato me refiro ao artesanato considerado "tipicamente Pataxó", ou seja, arcos, flechas, gamelas, colares e pulseiras de sementes e conchas, entre outros objetos de simbolismo indígena. Outros tipos de artesanato são comercializados em Coroa Vermelha, tanto por índios quanto por não-índios, mas esses não serão mencionados por não serem meu foco aqui. Também importa dizer que não necessariamente são apenas os índios que comercializam o artesanato Pataxó, sendo ele extremamente comum, inclusive, entre comerciantes não-indígenas nas cidades de Porto Seguro e Santa Cruz Cabrália.

Procurarei analisar o que chamo de aspectos estruturantes da circulação, ou seja, as condicionantes da produção a partir de três dimensões principais da vida para os Pataxó. A primeira delas seria a das relações de parentesco. A partir dessas relações se estabelece tanto a produção quanto a circulação do artesanato. Aquilo que é produzido e a forma como é comercializado, depende de uma série de relações entre parentes próximos e distantes. A segunda dimensão seria a da territorialidade. As formas de territorialização que presidiram a divisão da T.I Coroa Vermelha são também as que presidem a organização indígena do turismo. Finalmente, a dimensão das relações políticas, presididas tanto pelo parentesco, quanto pela territorialidade e pelas relações econômicas é uma dimensão fundamental que será abordada a seguir como estruturante da circulação e condicionante da produção do artesanato Pataxó.

A produção do artesanato Pataxó pode ser em parte explicada pelo conflito mencionado anteriormente. Como apenas 300 famílias da comunidade têm acesso às lojas de artesanato, existe um número considerável de famílias que vivem da produção do artesanato, mas não tem onde comercializá-lo, a não ser pelo pouco frutífero comércio ambulante na praia. Dos comerciantes entrevistados durante o levantamento de campo aproximadamente $60,7 \%$ (17) compram, ao menos uma parte do artesanato que vendem, de outros índios da Coroa Vermelha. Junta-se a isso o fato de que $100 \%$ (28) dos comerciantes entrevistados afirmaram não fabricar a totalidade de seu artesanato. Assim, é possível afirmar que existe uma considerável dependência dos comerciantes de artesanato em relação a famílias produtoras de artesanato da Coroa Vermelha.

No entanto, o retrato dessa dependência não é aquele em que os fornecedores exercem um controle sobre a revenda. A situação na Coroa Vermelha é a contrária. Como a alternativa para os produtores de artesanato à revenda aos lojistas é o comércio ambulante, para o qual muitos não têm condições físicas e que, de toda forma, é praticamente inócuo, o que acontece é a venda da produção artesanal por preços baixos, devido à grande concorrência. Grande parte dos comerciantes se especializa na venda e um número bastante pequeno deles fabrica grande quantidade do artesanato que vende. De todos os tipos de artesanato produzido pelos próprios comerciantes, apenas os colares, pulseiras e brincos atingem uma marca de produção 
significativa (50\% ou 14 comerciantes). Em todas as outras peças (gamelas, pentes, arcos, flechas, lanças, zarabatana, chocalho, cocar, petisqueira, colher de pau, anel, roupa, etc) o número de comerciantes que são também fabricantes é bastante inferior a 50\%, ficando numa média próxima a $35 \%$.

Além dessa situação interna, existe a produção e circulação entre aldeias. A aldeia de Coroa Vermelha fica num raio de até $200 \mathrm{Km}$ de várias outras aldeias Pataxó da região, como as de Barra Velha, Boca da Mata, Meio da Mata, Aldeia Velha e Mata Medonha. De algumas delas a distância é de até $50 \mathrm{Km}$, o que facilita grandemente o comércio e revenda entre aldeias. Dos comerciantes entrevistados 89\% (25), afirmaram comprar parte de seu artesanato de outras aldeias Pataxó. As aldeias mais citadas foram as de Boca da Mata (40\%), famosa por sua produção de gamelas, Barra Velha (32\%), tradicional produtora de colares e Mata Medonha (24\%), conhecida entre os Pataxó por uma produção variada, sendo nesse aspecto superior até à da Coroa Vermelha.

Essa situação acentua o caráter dos comerciantes de Coroa Vermelha como especialistas na revenda de artesanato, deixando grande parte da produção para os outros índios da aldeia e para índios de outras aldeias. As razões que explicam essa situação são diversas. Em primeiro lugar, o trabalho de compra e revenda do artesanato consome grande parte do tempo dos comerciantes. Além disso, a produção de artesanato é, do ponto de vista de um negócio coletivo, a grande saída vislumbrada por todas as aldeias da região, assim a produção é intensa. A única forma de se destacar economicamente da massa de produtores de artesanato é possuir um ponto de comercialização, o que acaba por obrigar ao proprietário a dedicação exclusiva a ela.

Assim, é possível fazer algumas considerações iniciais sobre a produção e a circulação do artesanato na aldeia de Coroa Vermelha. Em primeiro lugar, existe uma separação clara, embora não necessariamente estanque ou dicotômica, entre os produtores e os comerciantes de artesanato. A relação de força, economicamente falando, se exerce dos revendedores para os produtores. Os produtores vendem o artesanato a baixo preço em função da grande concorrência e grande parte do lucro fica com os revendedores. ${ }^{3}$ Em segundo lugar, ocorre a diferenciação de um segmento de especialistas na revenda de artesanato com interesses próprios, que não necessariamente se coadunam com os da liderança indígena, nem com os do restante da comunidade e passam a constituir uma força política considerável. Por fim, existe uma especialização das aldeias, que em parte tem relação com os tipos de matéria-prima encontrados em cada região e a qualidade dos artesãos, e que, em última instância, vive da revenda a Coroa Vermelha.

Dessa forma, a produção do artesanato Pataxó se estrutura com base numa relação de produção assimétrica, relacionada a um critério de antiguidade. Como mencionado anteriormente, apenas as famílias que já possuíam lojas no centro de artesanato indígena tiveram acesso garantido às lojas do novo centro de artesanato. Essas famílias obviamente foram as primeiras a chegar na região. $\mathrm{O}$ novo centro de artesanato tornou inócua a, já pouco efetiva, venda de artesanato ambulante na praia. Assim, as famílias produtoras que não foram contempladas com as lojas no centro de artesanato têm duas opções: comprar ou alugar lojas ou vender sua produção aos comerciantes que possuem loja. O aluguel de lojas, aliás, é uma forma de subsistência bastante comum entre as famílias possuidoras das lojas, já que o valor cobrado, que varia de $\mathrm{R} \$ 300,00$ a $\mathrm{R} \$ 400,00$ é uma segurança mensal que o comércio não oferece, embora este ofereça oportunidades de lucro maior na alta temporada. A formação de um grupo de revendedores produz um segmento mais próspero e enriquecido. Este grupo, cujas relações de poder já estavam estabelecidas pelo parentesco e pela antiguidade de ocupação da Coroa Vermelha as vê reforçadas pela prosperidade.

Sobre esse aspecto importa retomar 
algo do processo de formação da aldeia de Coroa Vermelha. O pajé Itambé, apontado por muitos índios, bem como pelos documentos oficiais (Carvalho e Sampaio, 1992) como o primeiro Pataxó a chegar à Coroa Vermelha, lembra que, na época, ele era um dos responsáveis pela organização comercial da praia de Coroa Vermelha e "distribuía os terrenos para os parentes que chegava". Os documentos oficiais relatam que desde 1973 a prefeitura "delimita lotes para a ocupação dos índios e lhes constrói casas, atraindo novos contingentes indígenas (Id.: 8). Embora esse relato oficial dê conta da delimitação de lotes para moradia, não menciona os critérios de sua distribuição, nem os da área de comércio. Sobre essas áreas é que Itambé afirma sua ingerência.

Itambé conta que distribuía as famílias ao longo da praia de Coroa Vermelha. Essa distribuição teve, como é comum entre os Pataxó, bem como em qualquer sociedade indígena, relações com o parentesco. As famílias que se dirigiram para Coroa Vermelha em seguimento à Itambé, considerando ter sido ele o primeiro $\mathrm{Pa}$ taxó da região, foram, em geral, aquelas próximas a ele nas relações de parentesco. Alguns sobrinhos, primos e famílias de amigos e conhecidos de Itambé estão entre os primeiros que chegaram à região e que possuem lojas no centro de artesanato.

Importa destacar também o que acontece com relação à padronização da produção do artesanato. Em uma estratégia que parecesse ter sido gerada por uma economia do conflito, os Pataxó atualmente comungam da opinião de que precisam minimizar as diferenças individuais entre o artesanato produzido, de forma a estabelecer um equilíbrio entre os comerciantes diante dos turistas. Cada loja tem o controle sobre seus estoques, variedades e tipos de produtos comercializados. No entanto, existe uma grande padronização, que faz com que cada arco, por exemplo, independente de por qual artesão tenha sido produzido, seja semelhante, assim como ocorre com os colares, pulseiras e toda a produção. Assim, não há competi- ção em relação às qualidades estéticas de cada tipo de artesanato e, embora aqui e ali tenham sido destacados pelos índios alguns artesãos, a idéia predominante é a de que todos são capazes de produzir as peças em igualdade de condições.

Essa estratégia evita criar mais uma frente de competição para os revendedores, frente essa que poderia favorecer os produtores. Se houvessem diferenças estéticas significativas entre as obras, os artistas mais reputados seriam mais procurados para a compra de suas peças e ganhariam poder de barganha, ainda que em detrimento da maioria dos produtores. No entanto, além de fazer parte de uma economia do conflito, evitando abrir mais uma frente, essa estratégia parece fazer parte do projeto de construção de indianidade Pataxó.

A todo tempo os comerciantes procuram destacar o fato de que o artesanato comercializado na Coroa Vermelha é "tipicamente" Pataxó. Assim, essas obras artesanais fariam parte do sistema de afirmação da etnicidade, investindo-se em símbolos específicos e atribuindo-lhes significado, de forma a reforçar um ponto de vista. Essa estratégia de acúmulo de capital simbólico exige a padronização como forma de afirmação do caráter específico. Assim, é possível raciocinar a respeito como Bourdieu, (2004: 112) que afirma que:

[...] os critérios objectivos de identidade étnica [...] são objectos de representações objectais, em coisas (emblemas, bandeiras, insígnias, etc.) ou em actos, estratégias interessadas de manipulação simbólica que têm em vista determinar a representação mental que os outros podem ter dessas propriedades e dos seus portadores.

Assim, a reprodução da idéia de que o artesanato faz parte do conjunto de características e tradições étnicas da comunidade precisa se apoiar na padronização das peças. Tudo se passa como se o conhecimento e a capacidade para produzi-las fosse homogeneamente distribuído entre todos na comunidade, como uma tradição compartilhada igualmente. Essa percep- 
ção cuidadosamente urdida e compartilhada se torna rapidamente um consenso do qual não se tem mais lembrança da origem. ${ }^{4}$ A manipulação simbólica de que essas representações são alvo seriam, mais propriamente, atos construtivos da uma identidade, sintetizados nesse trabalho pela expressão "projeto de construção de indianidade", do que atos de prestidigitação simbólica que a palavra manipulação poderia fazer supor.

Dessa forma, critérios de antiguidade, parentesco e divisão econômica de segmentos sociais são os motores do processo de produção e circulação do artesanato entre os Pataxó. Esse processo, como visto, se dá no interior da aldeia de Coroa Vermelha, relacionando produtores e revendedores indígenas da aldeia, bem como entre as diversas aldeias Pataxó.

\section{A circulação entre aldeias: espe- cialização e tradição no artesana- to Pataxó}

Como visto anteriormente as aldeias Pataxó da região de Santa Cruz Cabrália e Porto Seguro produzem um fluxo de circulação de artesanato importante para a economia local. Saindo da aldeia de Coroa Vermelha em direção à região de Caraíva, num raio de cerca de $170 \mathrm{~km}$, existem as aldeias de Aldeia Velha, Imbiriba e Barra Velha. Além delas, a aldeia de Boca da Mata também fica relativamente próxima de Coroa Vermelha. Entre estas aldeias é que se constitui o fluxo principal de circulação do artesanato Pataxó, com destaque para algumas delas.

A aldeia de Boca da Mata é a mais comentada e citada (32\%) pelos comerciantes como ponto onde eles fazem as compras de seu material. Esta aldeia se notabilizou por sua produção de gamelas, sendo considerada a de maior produção e de maior qualidade em relação a essa peça. A fama da aldeia é comentada por todos os comerciantes. Mesmo entre aqueles que afirmam produzir suas próprias gamelas têm Boca da Mata como uma referência, tendo lá aprendido a fazer ou considerando as lá produzidas melhores.
Em casos como o de Boca da Mata, em que as gamelas são de difícil produção e a qualidade dos artesãos indígenas é notória, existem outros interessados. Comerciantes não-indígenas regularmente visitam a aldeia visando comprar a produção de gamelas, ou mesmo trocá-la por alimentos. Esse interesse dos não-indígenas, em geral é visto pelos Pataxó como exploração, já que o artesanato é vendido a baixo preço para os brancos. Em relação a isso o Taquari comenta que "os brancos tiram o que o índio tem de mais valioso, que dá muito trabalho de fazer, por um prato de comida, um pouco de farinha”.

A aldeia de Boca da Mata, aliás, é sempre citada quando se trata de exemplificar a exploração dos brancos. Segundo os Pataxó, os brancos se aproveitam do fato de que os índios podem explorar a madeira da região. Dessa forma, conseguem produzir com menor custo e, portanto, vendem a um melhor preço. Essa situação é sempre apontada como a causadora, junto com seu isolamento, da degradação ambiental em que se encontra a aldeia. No entanto, recentemente a capacidade de competição dos comerciantes de Coroa Vermelha, bem como o aumento da facilidade de transporte até Boca da Mata, propiciaram que a aldeia vendesse aos próprios comerciantes indígenas, conseguindo um preço um pouco melhor.

A aldeia de Barra Velha foi também beneficiada pelo aumento da capacidade financeira dos comerciantes de Coroa Vermelha. A aldeia de Barra Velha é chamada pelos Pataxó de aldeia-mãe, pois seria o lugar de onde vem todos os Pataxó. Foi ali a região de seu aldeamento no século XIX. De lá saíram os atuais Pataxó da Coroa Vermelha nas décadas de 1960 e 1970. Nesse período, quando ocorrem as primeiras movimentações significativas dos Pataxó em direção a Coroa Vermelha, por exemplo, a aldeia de Barra Velha era considerada região extremamente remota. Embora o acesso siga sendo feito através de barcos, como tradicionalmente, recentemente, com o uso de bugres com tração nas quatro rodas, utilizados para percorrer os caminhos de areia e terra, 
esse transporte foi facilitado. Também foi favorecido pela melhoria da estrada e das linhas de ônibus que chegam às proximidades da aldeia, por exemplo, ao município de Caraíva. Essa situação favoreceu sobremaneira a possibilidade de revenda de artesanato por parte dos produtores de Barra Velha, que atualmente respondem por $10 \%$ das compras dos revendedores de Coroa Vermelha.

Deve-se destacar, em relação a Barra Velha, que a melhoria do transporte permitiu às famílias de produtores revenderem sua produção na própria região. A aldeia de Barra Velha está situada numa região de grande interesse turístico, estando inclusive ameaçada por interesses de empreendimentos hoteleiros e imobiliários na região. Por outro lado, sua localização permite à aldeia um acesso facilitado a hotéis e outros empreendimentos da região, que abrigam turistas eventualmente interessados na produção artesanal. Da mesma forma, a infra estrutura de acesso recentemente implantada permite aos índios receber visitas e visitar diversas partes da região para realizar trocas artesanais de forma facilitada.

\section{Significados do artesanato Pata- xó}

A reflexão sobre o significado do artesanato Pataxó é bastante complexa, pois envolve um conjunto de fatos e percepções cuja cronologia não pode ser facilmente reconstruída. O significado se constrói a partir de pequenos atos e reflexões que vão se tornando parte de uma trama complexa de significação. A partir de alguns dados do trabalho de campo procurarei aqui desdobrar essa trama. Para compreender os fluxos que constroem o significado do artesanato Pataxó utilizarei o raciocínio de Paul Veyne (1998: 42) sobre o conceito de trama:

Os fatos não existem isoladamente, no sentido de que o tecido da história é o que chamaremos de uma trama, de uma mistura muito humana e pouco "científica" de causas materiais, de fins e de acasos: de uma fatia da vida que o historiador isolou segundo sua conveniência, em que os fatos têm seus laços objetivos e sua importância relativa [...] Essa trama não se organiza, necessariamente, em uma seqüência cronológica: como um drama interior, ela pode passar de um plano para outro [...] A trama pode se apresentar como um corte transversal dos diferentes ritmos temporais, como uma análise espectral: ela será sempre trama porque será humana, porque não é um fragmento de determinismo.

Assim, a explicação sobre o significado do artesanato Pataxó que se pretende elaborar aqui é um tipo específico de contextualização. Uma prática que não busca uma seqüência cronológica sistemática e exaustiva. Ela se relaciona com o empreendimento humano de modo que, o importante para um evento é seu caráter humano e os fatos que são lembrados e re-trabalhados pelos atores envolvidos no contexto ao qual ele diz respeito.

\section{O artesanato Pataxó na relação com a sociedade envolvente: tra- dição e transformação}

O primeiro nó dessa trama está relacionado ao episódio que seria de fundação do artesanato Pataxó como se compreende hoje. Em relação a esse episódio as narrativas indígenas apresentam alguma variação. Todas as variações remetem a origem do artesanato, como hoje existe, à relação com a sociedade envolvente. Em algumas versões, o chefe de posto indígena da aldeia de Barra Velha, Leonardo é apontado como quem dá a sugestão de que os Pataxó deveriam produzir artesanato na década de 1960 e 1970. Segundo essa versão ${ }^{5}$, apresentada, entre outros, por Carvalho (1977) e Grünewald (1999), o chefe de posto teria mostrado aos Pataxó artesanatos de outros povos indígenas, comercializados com ajuda da Fundação Nacional do Indio (FUNAI). Esse teria sido o passo e o exemplo inicial que deram origem ao artesanato Pataxó tal como hoje existe. Segundo conta o Itambé ele 
teria dito "que ali tinha conchas e outras coisas que os Pataxó podiam usar para fazer artesanato e vender para os brancos." ${ }^{6}$

Essa narrativa já foi usada como uma justificativa para se compreender o artesanato Pataxó como uma tradição inventada (Grünewald, 1999). Embora a afirmação da criatividade cultural indígena seja um caminho de interpretação já clássico (Oliveira, 2004) e tenha apresentado grande contribuição teórica ao contexto etnográfico dos índios do nordeste, procurarei nesse trabalho outros caminhos interpretativos para compreender o artesanato Pataxó. A essa interpretação, assentada numa visão "desobjetificada" da tradição, atribuo a possibilidade de enxergar as continuidades da tradição Pataxó, como vislumbradas pelos índios, em seu projeto de construção de indianidade.

Considero, para tanto, tradição como sendo "ação culturalmente apropriada" (Toren, 1988:712 [trad. do autor]), Cristina Toren demonstra, em sua análise do contexto fijiano que a noção de tradição deve ser analisada a partir de seu significado local, o que para os fijianos, em sua interpretação, significa pensar a tradição como "a maneira local de fazer". Procurarei demonstrar a seguir que essa concepção pode ser aproximada de algumas formas de pensar a tradição entre os Pataxó.

No entanto, antes de partir para a análise de algumas concepções Pataxó de tradição é necessário repassar um aspecto em especial da literatura etnológica sobre os mesmos. Carvalho (1977: 382-3) demonstra que, embora tenha havido descontinuidade entre a produção artesanal anterior e a produção que se inicia a partir de 1971, os índios tinham memória àquela época (final da década de 1970) da tradição artesanal mais antiga. "Embora confessem que os "antigos" sabiam fazer arcos, flechas, lanças, com eles não aprenderam: "então, quer dizer que eu nunca vi eles fazer, mas eles falavam que tinham, o índio fazia."

Como já demonstrado longamente por Carvalho (1977), Carvalho e Sampaio (1992) e Sampaio (1994) existiu sempre entre os Pataxó uma tradição comercial como modalidade principal de relação com a sociedade envolvente. Essa tradição pode ser vislumbrada, tanto nos primeiros momentos de contato, com a troca de produtos da mata, quanto mais tarde, sobretudo depois de 1970 no contexto turístico. Esses mesmos relatos apontam para o fato de que o artesanato, do pouco que se sabe sobre sua produção, era majoritariamente de uso privado. Embora o artesanato não tenha, portanto, aparecido sempre como objeto de trocas considero que, tanto a possibilidade de que seja pequena sua descontinuidade temporal, quanto a longa tradição comercial Pataxó apontam para o fato de que o comércio de artesanato atual é mais uma linha de continuidade com o passado, através da qual se lê a história, do que uma ruptura.

O artesanato Pataxó atual é, na ótica que proponho, um retorno a uma prática antiga transformada e ressemantizada. Ao invés de um artesanato voltado para o uso privado, se passa a produzir um artesanato voltado para o comércio. Essa mudança terá claramente impactos na forma dos objetos produzidos, bem como em quais objetos passa a ser interessante produzir. Também é claro que essa mudança afetará as percepções sobre esse artesanato. A produção atual é largamente voltada para os adornos (cerca de $70 \%$ da produção dos entrevistados), que contam com maior apreciação dos turistas, e em menor quantidade para utensílios de uso doméstico.

Ainda assim, os utensílios domésticos são produzidos com o intuito de adornar mais do que de ser utilitários para os lares Pataxó, como se pode aperceber do esmero estético que lhes é empregado na produção e dos relatos dos índios. Ainda assim, devo ressaltar que a aldeia de Coroa Vermelha sempre teve vocação comercial, sendo esse um aspecto essencial de sua gênese (Sampaio, 1996). Vista por essa perspectiva a transformação na tradição nem pode ser considerada uma guinada, mas uma leve re-orientação.

A proposta de interpretação que faço aqui é a de que o artesanato Pataxó, em suas conformações atuais, se constitui 
como uma linha de continuidade da tradição. A um só tempo é linha de continuidade e elemento de transformação na tradição indígena, oriundo de uma relação com a sociedade envolvente e a conseqüente "modernização" da sociedade indígena. Assim, o artesanato, que em sua origem, antes do aldeamento em Barra Velha no século XIX, era ou parecia ser para utilização individual, desde seu retorno, na década de 1970 , se baseou em sua vocação comercial.

\section{Arte e souvenir: alguns significa- dos do artesanato e da tradição entre os Pataxó}

Tendo em vista as mudanças operadas na utilização e vocação fundamental do artesanato Pataxó, que datam da década de 1970 , se pode dizer que estas tenham gerado mudanças em sua significação. Essas mudanças de significado têm relação com o contexto cada vez mais acentuadamente comercial no qual o artesanato $\mathrm{Pa}$ taxó existe atualmente e que molda seus contornos de significação.

Como mencionei anteriormente, a mudança não diz respeito apenas à exacerbação da conotação comercial desse artesanato. Tendo em vista que essa conotação fez sempre parte de sua existência, a modificação que sua inserção no turismo produz não é tão importante se for analisada apenas como mercadorização. A mudança principal diz respeito às categorias estéticas utilizadas para designar o artesanato e para emitir percepções a respeito dele. Tendo já comentado a questão de que o artesanato passa a ser um emblema étnico, produzindo a sensação de que os conhecimentos e técnicas a ele relacionados são horizontalizados, importa destacar uma bifurcação em suas percepções para os Pataxó. Essa bifurcação se dá fundamentalmente em torno da idéia de tradição que está imbricada na produção do artesanato.

O artesanato Pataxó é tratado entre os índios a partir de duas perspectivas sobre sua significação. Quando perguntados sobre o significado do seu artesanato exis- tem dois conjuntos de referências que, embora não opostos, se diferenciam nas falas dos índios. Por um lado, ele pode aparecer como arte e, por outro, como lembrança, vista tanto da perspectiva do sinônimo de souvenir, quanto na perspectiva da lembrança evocada pelas categorias patrimônio e memória.

Dona Meruca foi a primeira pessoa que me apresentou o artesanato Pataxó como arte. Em 2005, primeiro ano em que tive contato com os Pataxó, enquanto comprava peças em sua loja ela me apresentava diversos aspectos do que seria a arte $\mathrm{Pa}$ taxó. Quando lhe perguntei mais a respeito ela me disse que a arte que estava por trás do artesanato vinha dos tempos de Barra Velha e que era "tradição antiga" entre os Pataxó. Dona Meruca é uma das habitantes de Coroa Vermelha que tem maior ligação com a aldeia de Barra Velha em sua vida cotidiana, viajando constantemente para lá. Meruca passou a infância em Barra Velha e se lembra de várias histórias dessa época. Seus filhos participam ativamente do movimento indígena na região e alguns deles exercem papeis importantes. A visão que ela apresentou sobre a arte Pataxó tem provavelmente relação com isso, pois uma de suas filhas é artista plástica graduada e tem suas obras bastante reconhecidas e conhecidas em toda a região, sobretudo pelos Pataxó.

Quando solicitei que me explicasse melhor o que seria a "arte Pataxó" Meruca me disse "é tudo aquilo que vem dos antigos, de Barra Velha, da raiz dos Pataxó, não importa onde você está hoje”. Para ela, arte Pataxó estava essencialmente ligada à idéia de tradição, só podia ser arte aquilo que fosse tradicional dos Pataxó. Entendi logo que essa idéia de tradição não tinha uma conotação estanque, pois ela considerava o que a filha fazia como arte tradicional, embora ela fosse mesclada com técnicas ocidentalizadas de produzir arte. As obras da filha de Dona Meruca tematizam sempre os Pataxó e sua cultura e, embora haja uma óbvia sofisticação da técnica, não abre mão de elementos rústicos.

Assim, o significado da arte Pataxó ti- 
nha para Meruca relação com o tradicional, mas não uma relação estanque. Sinalizava que o tradicional não era o objeto, mas a intenção estética e o modo local de fazer. Esse raciocínio pode se assemelhar ao de Reisinger e Steiner (2006: 68) para os quais a autenticidade, como propriedade do objeto tradicional no contexto turístico, não é "uma propriedade real do objeto turístico que pode ser medida de acordo com critérios absolutos e objetivos" (Trad. do autor). Para essas autoras, a autenticidade, que caracteriza o tradicional é subjetiva, resultado das representações e ações dos sujeitos, que se vêem como autênticos, visualizando-se numa situação livre dos constrangimentos sociais da vida cotidiana. Assim, a autenticidade do tradicional seria um esforço de subjetivação do coletivo onde, livre de certas amarras sociais, o sujeito é capaz de fabricar transformações na cultura tradicional.

Por outro lado, o artesanato Pataxó pode ser apresentado como lembrança, tanto no sentido de souvenir turístico como no sentido de memória, patrimônio. Essas duas categorias me foram apresentadas na convivência com os comerciantes do centro de artesanato indígena. A todo tempo eles tentam vender aos turistas aquilo que seria a lembrança dos Pataxó da Bahia, o artesanato. Nesse sentido, até muito simples, o artesanato é apresentado como um souvenir a ser utilizado como lembrança de uma viagem e se insere na agenda típica de uma viagem a um destino turístico. Esse me pareceu, desde as primeiras vezes que o ouvi, um significado aparentemente óbvio para o artesanato Pataxó. Se ele estava ali para ser vendido, poderia ser apresentado como uma lembrança de viagem, um souvenir.

Certa vez, no entanto, ouvi um artesão dizer a um turista: "essa peça é para você se lembrar, não só da Bahia e de Porto Seguro, mas da luta e da memória do povo Pataxó". Essa fala, mais parecida com uma artimanha de comerciante para vender o produto me chamou a atenção. Quando questionei ao Kapimbará o que ele quisera dizer com aquilo ele me respondeu, com um sorriso no canto dos lá- bios, de forma que para ele parecia óbvia: “o artesanato dos Pataxó não é só para vender para encher a barriga, se cada um turista que vier aqui e comprar essa peça e ouvir nossa história, se lembrar dela depois por causa do meu artesanato, como é que ia ser a Coroa Vermelha daqui há uns 10 anos, professor?". A frase do Kapimbará acompanhada de uma referência até certo ponto jocosa à minha condição de professor, gozando de uma posição supostamente superior à dele intelectualmente, me chamou a atenção. Para ele não fazia sentido como alguém na minha posição não entendia que o artesanato não era só para vender. $\mathrm{O}$ artesanato contava a história do povo e se essa história pudesse ser contada várias vezes, pelos diversos lugares do país e fora dele: será que Coroa Vermelha e a vida dos $\mathrm{Pa}$ taxó não poderia ser muito melhor?

Assim, esse último sentido do artesanato me foi apresentado num tom de questionamento e interrogação: como instrumento de comunicação, o artesanato não poderia contar a história dos Pataxó e ajudar a vencer uma batalha por reconhecimento de direitos pela qual já se lutou de tantas outras formas? O artesanato era afinal um instrumento de comunicação? A resposta a essas questões sempre me pareceu positiva, no entanto, restam investigar seus pormenores e saber exatamente como o artesanato Pataxó é um instrumento de comunicação.

\section{Considerações Finais}

Ao longo desse trabalho procurei discutir alguns aspectos que considero fundamentais para a compreensão do artesanato Pataxó. Em primeiro lugar, foi necessário proceder a uma descrição do lugar onde esse artesanato existe e para onde ele flui, o centro de artesanato indígena da Coroa Vermelha. Criado pelo governo federal como forma de propiciar infra-estrutura aos índios para continuar sua atividade comercial, rapidamente se tornou uma referência simbólica à vocação comercial de Coroa Vermelha.

Após uma descrição do centro de ar- 
tesanato ou do Parque Indígena, como o conjunto é chamado pelos Pataxó, passei a algumas descrições do artesanato e seu contexto de produção e circulação. Foi possível perceber que esse artesanato é produzido, em pequena escala, por quase todos os Pataxó, tanto de Coroa Vermelha, quanto de outras aldeias. No entanto, a posição comercial de que goza Coroa Vermelha e mais ainda as famílias proprietárias de lojas, cria uma especialização econômica, a dos revendedores, daqueles que abandonam a produção porque sua atividade de revenda não lhe permite mais o tempo para produzir. Essa nova segmentação social produz impactos sobre os produtores que, colocados na situação de ter que vender sua produção aos revendedores, não possuem poder de barganha em função da enorme produção e são obrigados a praticar baixos preços.

Sobre a produção foi possível notar também sua alta padronização em relação à forma de fazer, necessária não apenas para homogeneizar a oferta estética, favorecendo os revendedores ao não criar categorias de artistas especializados, mas, sobretudo com efeito diacrítico. Ao produzir a idéia de que o artesanato é um marcador étnico, precisou-se apoiar essa idéia na homogeneização do artesanato, aparecendo este como uma tradição horizontalmente distribuída na comunidade.

A circulação do artesanato, como procurei demonstrar, se dá dos produtores da Coroa Vermelha para os revendedores, bem como dos produtores de diversas aldeias para os revendedores na Coroa Vermelha. Essa circulação estabelece a especialização de algumas aldeias, tais como a de Boca da Mata, especializada em gamelas e a de Barra Velha, especializada em colares.

Por fim, em relação ao significado do artesanato demonstrei que ele pode variar de arte a souvenir, comportando alguns gradientes nessa escala. Todos esses gradientes comportam concepções locais de tradição, parecendo ser hegemônica a visão de tradição como forma local de fazer artesanato. Assim, aparecem para o artesanato significados tais como; memó- ria, tradição, patrimônio, entre outras categorias evocadas pela palavra lembrança. Em relação ao significado fica por ser esclarecida mais profundamente a questão do artesanato como prática comunicativa. Consegue o artesanato Pataxó transmitir as mensagens a que se propõe? Que efeitos causa nos turistas? E na sociedade envolvente e suas autoridades?

Nesse trabalho procurei, portanto, resumir alguns aspectos da produção, circulação e significados do artesanato $\mathrm{Pa}$ taxó. Esse esforço resultou no isolamento de alguns aspectos estruturantes desse circuito, tais como a construção da indianidade, os critérios de parentesco, as relações econômicas e as relações políticas entre aldeias. Essas relações são as mesmas componentes e estruturantes da sociedade Pataxó como um todo, diferenciando-se no campo do turismo e do artesanato por adaptações locais e genéricas, voltadas para finalidades práticas.

\section{Bibliografia}

Barth, Frederik

2000 "Os grupos étnicos e suas fronteiras". In Tomke Lask (org.) O guru, o iniciador e outras variações antropológicas Rio de Janeiro: Contra Capa.

Bourdieu, Pierre

2004 O poder simbólico. Rio de Janeiro: Bertrand Brasil.

Carvalho, Maria Rosário G.

1977 Os Pataxó de Barra Velha: seu subsistema econômico. Dissertação de Mestrado. Programa de Pós-Graduação em Ciências Sociais, UFBA, Salvador.

Carvalho, Maria Rosário. G. e Sampaio, José Augustro L.

1992 Parecer sobre o Estatuto Histórico-Legal das Áreas Indígenas Pataxó do Extremo Sul da Bahia. Salvador.

Grünewald, Rodrigo de Azeredo

1999 Os 'Índios do Descobrimento': tradição e turismo Rio de janeiro, UFRJ/ MN/PPGAS.

Oliveira, João Pacheco de (Org.). 2004 A viagem da volta: etnicidade, políti- 
ca e reelaboração cultural no Nordeste Indígena. Rio de Janeiro: Contra Capa/ LACED.

Peres, Sidnei

2004 "Terras indígenas e ação indigenista no Nordeste (1910-1967)". In: Oliveira, J.P. (Org.). A viagem da volta: etnicidade, política e reelaboração cultural no Nordeste Indígena. Rio de Janeiro: Contra Capa/ LACED.

Reisinger, Yvette e Steiner, Carol .J.

2006 "Reconceptualizing Object Authenticity". In: Annals of Tourism Research. 33 (1):65-86

Sampaio, José Augusto L.

1994 Breve Histórico da Presença Indígena e as Atuais Comunidades Pataxó do Baixo Extremo Sul da Bahia. Salvador.

Sampaio, José Augusto L.

1996 Sob o signo da cruz. Relatório circunstanciado de identificação e delimitação da terra indígena Pataxó de Coroa Vermelha. Salvador.

Toren, Chrstina

1988 "Making the present, revealing the past: The mutability and continuity of tradition as process". In: Man, New Series, Royal Anthropologic Institute of Great Britain and Ireland, 23 (4):696717.

Veyne, Paul

1998 Como se ecreve a historia: Foucault revoluciona a história. Tradução de Alda Baltar e Maria Auxiliadora Kneipp. Brasília: UnB

\section{NOTAS}

1 Esse artigo é uma visão revisada e modificada do artigo apresentado na XXVII Reunião Brasileira de Antropologia Belém-PA

2 FUNAI é a sigla para a Fundação Nacional do Índio. É o órgão que responde pela ação indigenista no âmbito do Estado brasileiro, atua com assistência aos índios sobretudo na questão relativa à posse de terras e exerce a tutela de acordo com a legislação brasileira.

3 É importante mencionar aqui que por outros mecanismos como a prestação de serviços e a solidariedade familiar, uma parte do lucro dos revendedores é redistribuída. Essa situação, se não evita um desconforto da comunidade, ao menos evita uma reação mais exasperada de vários dos Pataxó

4 Importa lembrar aqui, conforme o trabalho de Grünewald (1999: 210-232) que o artesanato Pataxó, ao menos em sua apresentação atual, remete aos anos 1960 e 1970 e é apresentado em narrativas diferentes pelos índios.

5 Adota-se aqui a narrativa sobre o chefe de posto Leonardo como a mais plausível e verossímil. As outras narrativas sempre se referem a um homem branco que teria dado a sugestão da produção do artesanato. Em algumas ele seria um chefe de posto com outro nome, em outras seria um homem branco que foi apenas visitar a aldeia e até existe uma versão em que o professor Pedro Agostinho da Silva aparece como quem teria feito essa sugestão. A última versão é especialmente fantasiosa, chegando a ser risível já que o professor algumas vezes já foi obrigado a negar essa versão.

6 É bom que diga aqui que essa lembrança do Itambé é uma lembrança de segunda mão, conforme lhe foi passado, pois o mesmo afirma que não esteve presente a esse momento. $\begin{aligned} \text { Recibido: } & 04 / 09 / 2010 \\ \text { Reenviado: } & 19 / 11 / 2010 \\ \text { Aceptado: } & 27 / 12 / 2010\end{aligned}$

Sometido a evaluación por pares anónimos 